\title{
Assessing the interrelationships between customer satisfaction, perceived value and behavioral intention among Maldivians seeking medical care within medical tourism services: Empirical evi- dence from the Maldives
}

\author{
Ahmed Ali Jaleel $^{a^{*}}$, Mohd Shukri Ab Yajid ${ }^{b}$, Ali Khatibi ${ }^{b}$ and S. M. Ferdous Azam ${ }^{b}$
}

${ }^{a}$ PhD Candidate, Post Graduate Centre, Management and Science University, University Drive, Off Persiaran Olahraga, Section 13, 40100, Selangor, Malaysia ${ }^{b}$ Graduate School of Management, Management and Science University, University Drive, Off Persiaran Olahraga, Section 13, 40100, Shah Alam, Selangor, Malaysia

\section{H R O N I C L E}

\section{Article history:}

Received: November 18, 2020

Received in revised format:

December 282020

Accepted: January 26, 2021

Available online:

January 26, 2021

Keywords:

Behavioral Intention

Customer Satisfaction

Maldives

Medical care

Perceived Value

Structural Equation Modeling

(SEM)

\section{A B S T R A C T}

Empirical studies related to interrelationships between variables perceived value, customer satisfaction and behavioral intention conducted in the Maldives context and in the medical care industry is very rare. A quantitative cross-sectional study conducted in natural settings using a survey questionnaire to assess the interrelationships between above mentioned variables by utilizing a conceptual model created from three interrelationship models obtained from previous research. Data collected from willing participants across the 19 atolls resulting in a total of 385 responses obtained after data cleaning. A stratified proportionate random sampling method used. SPSS 25.00 and AMOS 23.00 used as analysis tools. The Sobel test applied to analyze the mediating effect of customer satisfaction on the relationship between perceived value and behavioral intention which confirmed a positive and significant relationship between perceived value, customer satisfaction and behavioral intention. Study rejected the hypothesis which test the mediation of customer satisfaction on the relationship between perceived value and behavioral intention. This study is first of its kind to generalize findings on Maldivian's medical seeking behavior, and results helps policymakers, medical practitioners, medical institutions, and respective administrations to provide better customer perceived value towards providing higher customer satisfaction, which in effect improve customer behavioral intention towards medical care service providers.

(C) 2021 by the authors; licensee Growing Science, Canada

\section{Introduction}

The study is conducted in the Maldives which comprise of 20 administrative atolls with over 188 uninhabited islands with a total population of 557426 (National Bureau of Statistics - Maldives, 2020) and the annual population growth at 1.65 (National Bureau of Statistics - Maldives, 2019). The Worldometer (2020) estimates a population of 540,544 at mid-year indicating an equivalent to $0.01 \%$ of the total world population. The Maldives health and medical care structured as a five-tiered referral system, supported by both public and private support (Health, Ministry of. 2017). The medical service providers identified for this research are the medical institutions at tertiary located nationwide and registered as hospitals at the Ministry of Health, Maldives. The National Bureau of Statistics (2019) indicates that the total inpatients at private hospitals total to 368,553 whereas this figure is 590,364 in hospitals in Male' City, Regional Hospitals have had 637,497 cases, and the Atoll hospitals had a total outpatient's figure of 695,543 . There are 899 doctors and 2753 nurses to serve the entire population. The accessibility of people in many islands to medical facilities throughout the Maldives is challenging due to the geographical nature of the country and the transportation by sea can be impacted by unfavorable weather conditions. In addition to these natural causes, the drug abuse situation among the youth, the changing contemporary lifestyle which leads to leading causes of death

* Corresponding author.

E-mail address: jaleel.aa@gmail.com (A. A. Jaleel) 
in the Maldives which include cardiovascular diseases, chronic respiratory diseases, accidents and injuries, diabetes and cancer also influence the general well-being of the community which has a huge youth population. Never-the-less, there is a rising burden on medical services induced by the ongoing internal migration from other islands to the capital Male' City which forced the need to improve the medical care system to meet the growing demands and challenges of social determinants for medical care.

Few studies have been conducted on perceived value in different industries in the Maldives which suggests that further studies are required to generalize the findings (Waheed \& Hassan, 2016). A more recent study in Indonesia also concluded that further research in other research contexts is required to analyze behavior such as customer satisfaction, behavioral intent and customer loyalty (Rahayu et al., 2020). This research aims to: (1) test the effect of perceived value on customer satisfaction, (2) test the effect of customer satisfaction on behavioral intention and (3) test the mediation effect of customer satisfaction on the relationship between perceived value and behavioral intention, based on findings from previous literature. As current literature offers inadequate information on Maldivians background, and their decision-making factors in the choice of local and overseas medical care services, the results of this empirical study fill this gap and provide better decision making by relevant stakeholders in the medical care industry and further cross references to the Maldives National Healthcare Master Plan. The results of this study further enrich Maldivian literature on values, customer satisfaction and medical seeking behavior which is a much-needed future research area for the Maldives set out in the National Health Research Council Bulletin VI (Health, Ministry of., 2019).

\section{Literature review}

The variables selected for this study include Perceived Value, Customer Satisfaction, and Behavioral Intention. The sections below provide relevant literature from both theoretical and empirical perspective for the three specific variables and the relationships among them.

\subsection{Perceived value}

The perceived value is today considered one of the most prominent antecedents of customer satisfaction (Egert \& Ulaga, 2002) as well as loyalty (Cronin et al., 2000), and also an issue relevant to the medical care services. Perceived value is defined as the customer's overall assessment of the benefits they receive relative to the sacrifice they make (Fornell et al., 1996; Zeithaml, 1988). Many researches have been carried to study perceived value and its relationships with a number of different variables (Ahn and Thomas, 2020; Karunaratna \& Kumari, 2018; Patterson \& Spreng, 1997; Oh, 1999; Zeithaml, 1988). The perceived value was found to positively affect customer satisfaction. Prior research provided insight that perceived value is a general assessment of the utility of a product based on the understanding of what is offered and what is given (Zeithaml, 1988). Chahal \& Kumari (2012) explained that in the medical industry, customer-perceived interest includes acquisition value, transaction value, productivity value, aesthetic value, social contact value, and self-gratification value. Grönroos (2017) explains that customer value can be measured not only just for monetary impact but also for customer satisfaction, quality of service, brand perception, length of customer relationships, customer base turnover, willingness to pay, employee loyalty, and employee turnover. Ahn \& Thomas (2020) revealed that the four dimensions of perceived value, namely economic, social, hedonic, and altruistic values do not directly affect customers' behavioral intention towards integrated resort brands in Malaysia. Mahmoud et al., (2018) found in a study of the telecommunication industry that when customers perceived to benefit high functional, emotional, and social values from the service providers, they are more optimistic about the experience of consumption, purchasing decision, and satisfaction. A recent study carried out using PERVAL scale in the context of a Public University Hospital in Indonesia (Fitriani et al., 2019), revealed that perceived value is positively correlated to customer satisfaction. It also found that the functional value contributed most to perform the perceived value. Al-Gharaibah (2020) found that perceived value is more important than customer satisfaction in his study of customer retention in five-star hotels in Jordan. This study utilizes the functional values, emotional values and social values as dimensions of variable perceived value.

\subsection{Customer satisfaction}

Customer satisfaction is a key notion in marketing as it plays a critical role in meeting the needs and wishes of valuable customers (Martinaityte et al., 2019), and for business entities, customer satisfaction is one of the key successful factors (Adikaram \& Khatibi, 2016). Previous research claims that academics do not have a single universally accepted concept of customer satisfaction. Gronroos (1990) claims satisfaction is merely the end-results of the customer perception and the actual quality of the product. Parasuraman et al., (1985) considers satisfaction as a positive or negative outcome of a process of comparison between received service and the initial expectation. According to Monoarfa \& Usman (2020), the ExpectationDisconfirmation Model (Oliver, 1980) which align with Gronroos (1990) view can be used to explain customers' expectation of service levels in the medical industry. Oliver (1980) conceptualized satisfaction using principles of expectation-disconfirmation, and explained satisfaction as the summary psychological state arising from the combination of emotions surrounding unconfirmed expectations with the prior feelings of the customer about the consumption experience. Another study (Oliver, 2014) revealed that satisfaction is a general psychological condition and is typically the product of emotional aspirations and previous shopping behaviours experience. 
The satisfied customers are critical for hospitals, because they are more likely to use the medical service, follow the recommended medical plan, maintain the relationship with a particular service provider, and recommend service providers to other users (Hekkert et al., 2009). A recent research (Barari et al., 2020) shows that in the context of shopping experiences, affective experience has a greater effect on customer loyalty and positive word-of-mouth compared with cognitive experience. The medical care customer's happiness is without question the passport for productivity and profitability of an institution in the medical care industry. Holbrooks (1994) proposes that one of the goals of marketing activity is customer satisfaction. Kotler \& Armstrong (2004) agrees with Holbrook's view and explains that consumer satisfaction is an integral aspect of marketing, or a fundamental concern. A strong linear association was identified between satisfaction and functional values, as well as a strong linear association between satisfaction and social values (Budreviciute et al., 2019). Singh \& Soderlund (2020) advocates that the higher the overall customer satisfaction, greater repurchase intention and positive word-of-mouth, considering customer satisfaction is a key driver leading to higher intention to purchase, and positive word-of-mouth recommendations.

\subsection{Behavioral Intention}

Many researches have been conducted on behavioral intention and its relationships with a number of different variables (Barari et al., 2020; Ajzen, 1991; Chatterjee et al., 2018; Karunaratna \& Kumari, 2018; Oliver, 2014). Ajzen (2020) revealed that over 2000 empirical studies used the theory of planned behavior to successfully explain and predict behavior in multiple behavioral domains. According to the Theory of Planned Behaviour (Ajzen, 1991), the behavioral attitude and perceived control are identified as the antecedents of behavioral intention. In the literature, it has been long considered the precedent of behavioral intention including intention to repurchase or reexamine as well as to conduct word of mouth (Chen \& Tsai, 2007). Perceived behavioral control plays a significant control to persuade customers to purchase alternative medicine and to win customers trust in the alternative medicine industry in Malaysia (Haque et al., 2020).

Chenal and Bala (2010) explained that medical customers' loyalty is important for customer retention, and survival of the service provider in competitive markets like the medical care industry. Barari et al., (2020) suggested that service providers should consider overall customer experience, consideration should be given to both positive and negative customer experiences allow dissatisfied customers to share their negative experience with others. Willis et al., (2020) used perceived behavioral control, attitude, subjective norm, descriptive norm and injunctive norm as antecedents to intention in a recent study, and suggested that researches should pay attention to group processes in addition to individuals when trying to predict one's attitude, perceived behavioral control and perception of social norms. Awn \& Azam (2020) found that subjective norms and attitude plays an essential role in the intention to invest, where the attitude has a positive and significant effect on intent to invest in Islamic bonds among Libyan investors in the banking industry. Albattat and Romli (2017) explained that the revisit intention of customers to a specific destination may be influenced by performances, promotional efforts and related public relation activities at the specific destination. Knoll (2017) conducted behavioral observations among Maldivians travelling through nine atolls in the Maldives to seek medical treatments over a period of two years to conclude that it is unclear why Maldivians in outer area region islands are travelling directly to capital city of Maldives instead of moving through a series of islands, atolls, and through the national medical and healthcare referral systems.

\subsection{The relationships between perceived value, customer satisfaction and behavioral intention}

Alwashdeh et al., (2020) revealed that perceived value like performance value, value for money, and social values has a significant relationship in terms of a positive direct impact on customer satisfaction., also these three factors has a substantial relationship with regard a positive direct effect on Behavioral Intention, specifically eWord-of-Mouth. Kotler and Armstrong (2014) identified that customer value and customer satisfaction as the building blocks of a relationship. Literature reveals many studies carried to identify the impact of perceived value on customer satisfaction (Konuk, 2019; Oliver, 1980; Alwashdeh et al., 2020). Sudari et al., (2019) found that price has a positive effect on customer satisfaction whereas customer satisfaction has a positive effect on customer loyalty. Although price is the primary focus of the customers, other elements should be improved towards gaining higher customer satisfaction and behavioral intent, suggesting that further research with factors such as customer perceived value such as financial, emotional, and social values can affect customer satisfaction and behavior. Recent studies have been carried out to identify the impact of customer satisfaction on behavioral intention, which revealed that there is a positive and significant relationship between customer satisfaction and behavioral intention among airport passengers in Brazil (Bezerra \& Gomes, 2020), in organic food restaurants (Konuk, 2019). Haji et al., (2021) found that perceived value does not have a significant and positive effect on behavioral intention among tourists visiting Dodola Island in Indonesia, but it was found that perceived value increases tourists' satisfaction as tourists gave a positive evaluation of their satisfaction resulting from perceived value. Researches revealed positive and significant relationship between perceived value and customer satisfaction in hospitality industry in Cyprus which includes four-star and five-star hotels (Hayat \& Esenyel, 2020), among visitors to attraction parks in Malaysia (Albattat \& Romli, 2017), in primary health care centres in United Arab Emirates (Aburayya et al., 2020), in chemical industry in Indonesia (Samudro et al., 2020), and in organic food restaurants (Konuk, 2019) which revealed that customer satisfaction act as a partial mediator among perceived value and behavioral intention, indicating that behavioral intention is influenced by customer satisfaction. Although these studies provide empirical findings to contribute to minimise existing gaps in literature, recent research concluded by Rahayu et al., (2020) 
also suggested that further research is needed to develop different concepts and contexts especially among Muslim consumer behavior such as behavioral intention, customer loyalty, and customer satisfaction.

\section{Research hypothesis}

Based on debates and discussions in literature review provided above, this study proposes the following hypotheses:

H1: Perceived Value has a positive impact on customer satisfaction.

H2: Perceived Value has a positive impact on behavioral intentions.

H3: Customer satisfaction has a positive impact on behavioral intentions.

H4: Customer satisfaction mediates the relationship between perceived value and behavioral intentions.

\section{Study design, measures and research instrument development}

This section explains the research methodology which includes study design, measures and research instrument development.

\subsection{Study design}

This study is a cross-sectional, performed in a natural setting where limited interference from the researcher and administrators involved, and a quantitative approach to analyze, which is positivist in nature, using a self-administered questionnaire. This choice of approach considered as the analysis encourages behavior prediction from a population which is otherwise too large to observe directly. The data collection took place over a period of three months at the end of year 2019. The research was planned for the analysis based on available literature to cover perceived value, customer satisfaction, and behavioral intentions. There were two parts to this survey. Section one comprises data collection of the demographic characteristics of the respondent: gender, age, and residential area, highest level of completed education completed, occupation, medical care provider, and number of visits to receive medical care over the past 12 months. Section two involves items scales to collect data related to the perceived value, customer satisfaction, and behavioral intentions related to decisive moments from Maldivian's medical care experience encountered at respective medical care service providers.

\subsection{Measures}

According to the scales adapted in the study stipulated in Table 1 below, a self-administered survey questionnaire with 27 items was designed. A 1-5 Likert scale used where one (1) = strongly disagree, two (2)= disagree, three (3)= neither disagree nor agree, four $(4)=$ agree, and five $(5)=$ strongly agree).

\section{Table 1}

Items included in this survey

\begin{tabular}{lll}
\hline Construct & Number of items & Instrument adapted from \\
\hline Perceived Value (PV) & 9 & Lin, \& Huang (2018); Waheed \& Hassan (2016). \\
Customer Satisfaction (CS) & 7 & Ahmed et al., (2017); Chatterjee et al., (2018). \\
Behavioral Intentions (BI) & 11 & Sharma (2017); Altaf et al., (2018). \\
\hline
\end{tabular}

\section{Empirical analysis and discussions}

This section provides main findings, analysis and discussions on demographic characteristics of the respondents, statistical deviations, average variance extracted, composite reliability, factor loadings and reliability test results, the mediation test on the relationship between independent variable and dependent variable, and hypothesis test results.

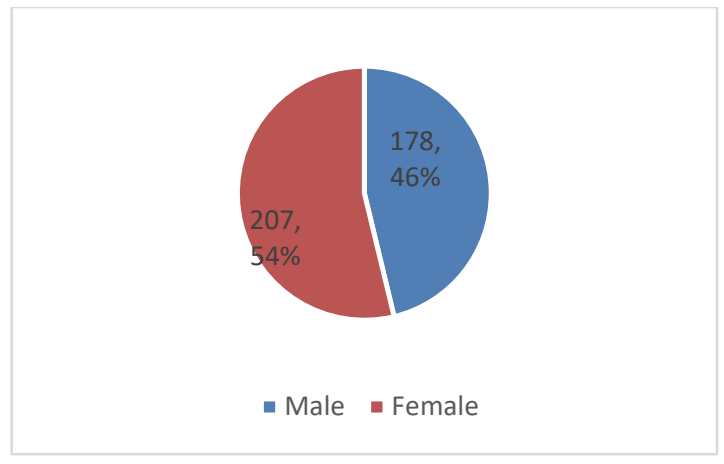

Gender

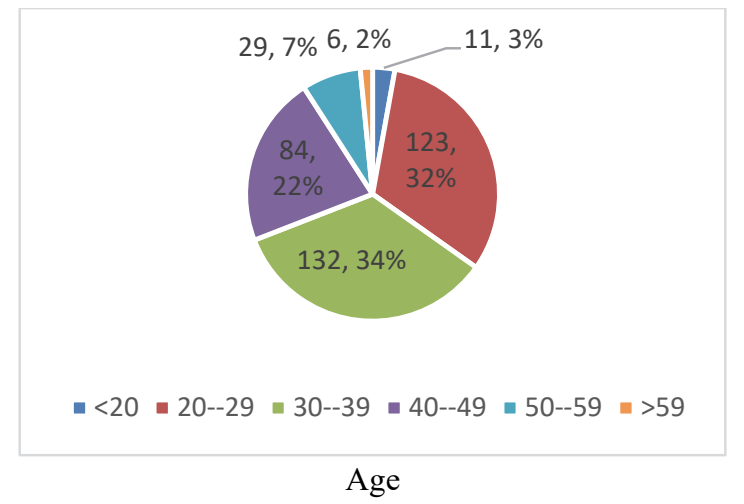

Age

Fig. 1. Demographic characteristics of the respondents 
Fig. 1 provides the responding samples' demographic characteristics, along with the number of responses and percentages. The overall mean scores, and the standard deviation for the scale items for perceived value, customer satisfaction, and behavioral intention are shown in Table 2, Table 3, and Table 4 respectively. Fig. 1 above reveals that the majority of the respondents are female, representing $53.77 \%$, whereas male representation of $46.23 \%$, indicating a female bias. The age distribution indicates adequate responses from the more active younger generation in the population which is between the ages 20-39 years.

Table 2, Table 3, and Table 4 provide results for the standard deviation which measures the amount of variability, and provides an indication of how far the individual responses to a question vary or deviate from the mean. It explains how spread out the responses are. The sample mean given is an estimated value of the population mean. The Average Variance Extracted (AVE) value measures the degree of reliability. The Composite Reliability (CR) value measures the convergent validity. Bartlett's test of sphericity and Kaiser-Meyer-Olkin (KMO) were applied to analyze the data adequacy and relevance of data for factor analysis.

Table 2

Perceived value scores

\begin{tabular}{|c|c|c|c|c|c|c|c|}
\hline Measure and Item & Mean & $S D$ & $A V E$ & $C R$ & Factor loading & $K M O$ & $\alpha$ \\
\hline Functional value in terms of convenience. & 3.41 & 1.001 & 0.721 & 0.944 & 0.790 & 0.943 & 0.951 \\
\hline Functional value in terms of professionalism. & 3.55 & 0.993 & & & 0.880 & & \\
\hline $\begin{array}{l}\text { Functional value in terms of better service compared to other service pro- } \\
\text { viders. }\end{array}$ & 3.46 & 1.030 & & & 0.818 & & \\
\hline $\begin{array}{l}\text { Emotional value consists in terms of excitement in receiving medical } \\
\text { care. }\end{array}$ & 3.27 & 1.031 & & & 0.852 & & \\
\hline Emotional value in terms of memories in receiving medical care. & 3.30 & 0.999 & & & 0.861 & & \\
\hline Emotional value in terms of pleasantness in receiving medical care. & 3.40 & 1.028 & & & 0.865 & & \\
\hline Social value given in terms of of self-image. & 3.40 & 1.028 & & & 0.848 & & \\
\hline Social value given in relation to social environment in terms of respect. & 3.46 & 1.045 & & & 0.856 & & \\
\hline $\begin{array}{l}\text { Social value given in relation to social environment in terms of relation- } \\
\text { ships. }\end{array}$ & 3.41 & 0.986 & & & 0.869 & & \\
\hline
\end{tabular}

Table 2 above shows the mean scores and the standard deviations (SD) for the service quality (SQ) construct, and the SD for Perceived Value items found to be between 0.985 to 1.045 . The lowest mean score is 3.27 whereas the highest score is 3.55 . Acceptable values of convergent validity achieved as the Composite Reliability (CR) values are above 0.9 . The average Variance Extracted (AVE) value of 0.721 indicates a satisfactory degree of reliability. The KMO value of 0.943 and the Bartlett's test of sphericity is found to be significant at $p$ value $0.000(0.001)$ which is less than 0.05 indicating relationship between variables are significant.

Table 3

Customer Satisfaction scores

\begin{tabular}{|c|c|c|c|c|c|c|c|}
\hline Measure and Item & Mean & $S D$ & $A V E$ & $C R$ & Factor loading & $K M O$ & $\alpha$ \\
\hline Satisfied with the medical care & 3.56 & 1.052 & \multirow[t]{7}{*}{0.706} & \multirow[t]{7}{*}{0.922} & 0.904 & \multirow[t]{7}{*}{0.903} & \multirow[t]{7}{*}{0.951} \\
\hline Satisfied with the medical facilities & 3.59 & 1.095 & & & 0.898 & & \\
\hline Satisfied with the services by medical staff & 3.58 & 1.058 & & & 0.896 & & \\
\hline $\begin{array}{l}\text { Satisfied, considering medical care I received is exactly what I } \\
\text { needed }\end{array}$ & 3.49 & 1.066 & & & 0.886 & & \\
\hline $\begin{array}{l}\text { My emotional experience during medical care was an enjoyment - } \\
\text { defined as delighted, happy, joyful }\end{array}$ & 3.24 & 1.165 & & & 0.827 & & \\
\hline Satisfied with the admission / administrative procedures & 3.09 & 1.149 & & & 0.722 & & \\
\hline Satisfied with the discharge (release) procedures after medical care & 3.11 & 1.169 & & & 0.724 & & \\
\hline
\end{tabular}

Source: Primary data processed on SPSS, 2020

Table 3 above shows the mean scores and the standard deviations (SD) for the customer satisfaction (CS) construct. The standard deviation for Customer satisfaction items found to be between 1.084 to 1.171 . The lowest mean score is 3.09, and the highest score is 3.59. Acceptable measures of convergent validity achieved considering that the composite reliability (CR) values are above 0.7 , and the AVE values are all above 0.5 indicating a satisfactory degree of reliability. The KMO value of 0.0 .903 and Bartlett's test of sphericity is found to be significant at $p$ value 0.001 which is less than 0.05 indicating a significant relationship between variables. Table 4 shows the mean scores and the standard deviations (SD) for the behavioral intention (BI) construct, where the Standard Deviations found to be between 1.127 to 1.466. The highest mean score of 4.05, and a lowest mean score of 2.93 identified. A satisfactory degree of reliability achieved as the AVE values are all above 0.5 , whereas the Composite Reliability (CR) values above 0.7 indicate acceptable measure of convergent validity. The KMO value of 0.907 and the Bartlett's test of sphericity is found to be significant at $p$ value 0.001 which is less than 0.05 indicating relationship between variables. According to Table 3, 4 and 5 above, the values for Chronbach's alpha $(\alpha)$ which measures internal reliability of the data set for all the constructs are above 0.9, indicating an excellent reliability result. Nunnally (1978) suggested that a coefficient alpha score of 0.70 or above is required to retain an item in a scale. The values of Cronbach's alpha are above 0.9 due to the facts that alpha increases due to the number of items, item correlation, assumptions of alpha (Duhacheck et al., 2005; Bandalos, 2018). 


\section{Table 4}

Behavioral Intentions Scores

\begin{tabular}{|c|c|c|c|c|c|c|c|}
\hline Measure and Item & Mean & $S D$ & $A V E$ & $C R$ & Factor loading & $K M O$ & $\alpha$ \\
\hline I would always visit this specific medical service provider & 3.51 & 1.013 & 0.658 & 0.783 & 0.809 & 0.907 & 0.926 \\
\hline $\begin{array}{l}\text { I will not choose any other medical service provider if this medical } \\
\text { service provider is ready to provide medical care }\end{array}$ & 3.17 & 1.074 & & & 0.814 & & \\
\hline I would visit this medical service provider regardless of their price & 3.27 & 1.017 & & & 0.657 & & \\
\hline I would consider this medical service provider as my first choice & 3.42 & 0.995 & & & 0.807 & & \\
\hline $\begin{array}{l}\text { My family and relatives think I should visit this medical service pro- } \\
\text { vider }\end{array}$ & 2.98 & 1.252 & & & 0.753 & & \\
\hline My friends think I should visit this medical service provider & 2.85 & 1.224 & & & 0.749 & & \\
\hline $\begin{array}{l}\text { My close acquaintances who had previous medical care from this med- } \\
\text { ical service provider believes I should also visit this medical service } \\
\text { provider }\end{array}$ & 3.00 & 1.211 & & & 0.747 & & \\
\hline My doctor thinks I should visit this medical service provider & 2.94 & 1.184 & & & 0.690 & & \\
\hline $\begin{array}{l}\text { I would recommend this medical service provider to someone else } \\
\text { through social media }\end{array}$ & 2.94 & 1.228 & & & 0.815 & & \\
\hline $\begin{array}{l}\text { I would encourage friends on social media to visit this medical service } \\
\text { provider }\end{array}$ & 2.92 & 1.231 & & & 0.821 & & \\
\hline $\begin{array}{l}\text { I am proud to tell others on social media that I use service from this } \\
\text { medical service provider }\end{array}$ & 2.93 & 1.295 & & & 0.755 & & \\
\hline
\end{tabular}

5.1 Analyzing the mediating effect of customer Satisfaction on the relationship between perceived value and behavioral intention

Structural Equation Modelling (SEM) constructed to analyze the relationships hypothesized for this study. Fig. 2 below shows the structural model used to obtain results for the mediation effect of customer satisfaction (CS) on the relationship between perceived value (PV) and behavioral intention (BI).

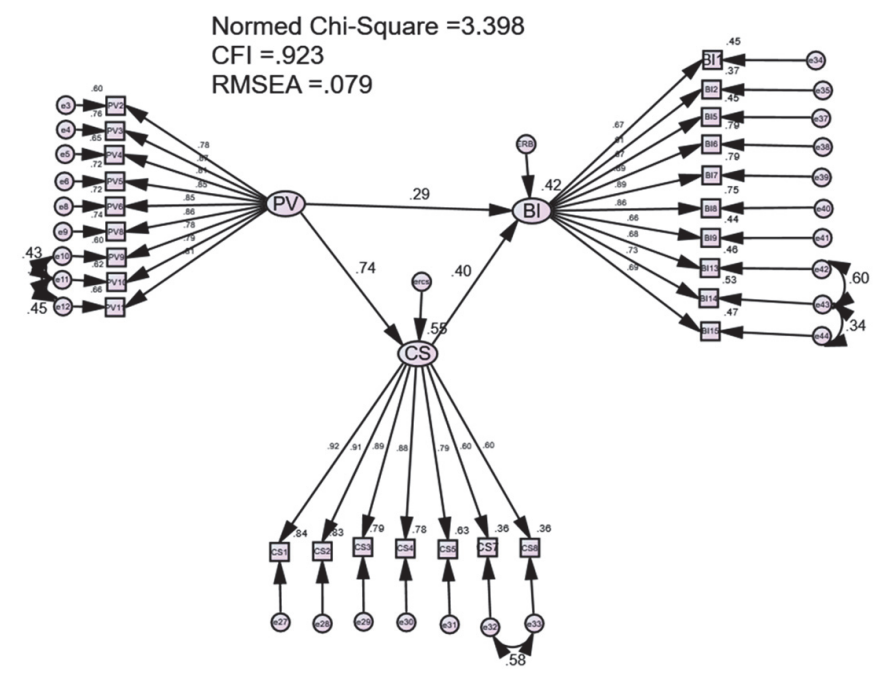

Fig. 2. Structural equation model to obtain the measures of mediation by Customer Satisfaction

The overall fit of the modified structural model from the AMOS output obtained. The results indicate an excellent fit of the structural model. The fit indexes are tabulated in Table 5 provided below:

Table 5

Fit Index obtained for this study

\begin{tabular}{|c|c|c|c|}
\hline & Acceptable fit indices & Output for this study & Observation \\
\hline $\begin{array}{c}\text { Chi-squared } \\
\text { DF }\end{array}$ & Dependable on the sample size. & $\begin{array}{c}985.355 \\
377-87=290\end{array}$ & \\
\hline P Value & 0.000 & 0.000 & Good fit attained at 5\% \\
\hline Normed Chi-Squared & $\begin{array}{l}\text { Between } 2.00 \text { and } 5.00 \text { acceptable. Below } 2.0 \text { is very } \\
\text { good (Hair et al., 2019) }\end{array}$ & 3.398 & \multirow{3}{*}{ Acceptable fit values attained } \\
\hline CFI & Above 0.900 (Hair et al., 2019) & 0.923 & \\
\hline RMSEA & Below 0.08 (Hu \& Bentler, 1999; Hair et al., 2019) & 0.079 & \\
\hline
\end{tabular}

Table 5 above reveals that the goodness of fit indices Normed Chi-squared value 3.398, degree of freedom of $378-61=317$, $\mathrm{P}$ value of $0.000, \mathrm{CFI}$ value of 0.923 , and the RMSEA value of 0.079 , which is well below the recommended cut-off value of 
0.08 (Hair et al., 2019; Hu and Bentler, 1999). These results provide sufficient unique information to evaluate this study model. The results for the regression weights without mediation and with the mediation for the three variables of this study (Perceived Value, Customer Satisfaction, and Behavioral Intention), and standardized regression weights with and without mediation effect of customer satisfaction is tabulated in Table 6 below:

Table 6

The regression weights for the intervening effect of Customer Satisfaction

\begin{tabular}{|c|c|c|c|c|c|}
\hline Regression & out Mediat & & & & \multirow{2}{*}{$\begin{array}{c}\begin{array}{c}\text { Standardized Re- } \\
\text { gression Weights } \\
\text { without Mediation }\end{array} \\
\text { Estimate }\end{array}$} \\
\hline & Estimate & S. E. & C. $R$. & Pvalue & \\
\hline Behavioral Intention $(\mathrm{BI}) \leftarrow$ Perceived Value & 0.645 & 0.065 & 9.873 & $* * *$ & 0.587 \\
\hline \multicolumn{4}{|c|}{ Regression Weights with Mediation } & & $\begin{array}{l}\text { Standardized Re- } \\
\text { gression Weights } \\
\text { with Mediation }\end{array}$ \\
\hline & Estimate & S.E. & C. $R$. & Pvalue & Estimate \\
\hline Behavioral Intention $\leftarrow$ Perceived Value & 0.324 & 0.077 & 4.196 & $* * *$ & 0.292 \\
\hline Customer Satisfaction $\leftarrow$ Perceived Value & 0.891 & 0.059 & 15.083 & $* * *$ & 0.739 \\
\hline Behavioral Intention $\leftarrow$ Customer Satisfaction & 0.372 & 0.065 & 5.7221 & $* * *$ & 0.404 \\
\hline
\end{tabular}

Table 6 above confirms the impact of the intervening variable Customer Satisfaction on the relationship between Perceived Value and Behavioral Intention. The rejection of null hypotheses for this study is accepted as results indicated as three stars $(* * *)$ in Table 6 provide evidence that $\mathrm{p}$-value is less than 0.01 revealing the covariance between the construct variable relationships under test is significantly different from 0 at the 0.05 level, and the results of p-values are below 0.05 The Critical Ratio (C.R.) values for all the three relationships under testing were greater than \pm 1.96 , indicating significant regression coefficient is achieved. The results above indicate that estimates are positive values, which are significant. The intervening effect of customer satisfaction on the relationship between perceived value and behavioral intention by conducting the Sobel test. Fig. 3 below shows the schematic diagram on the arrangements of the Perceived Value-Customer Satisfaction-Behavioral Intention paradigm, and the results obtained from Table 6 for the respective relationships.

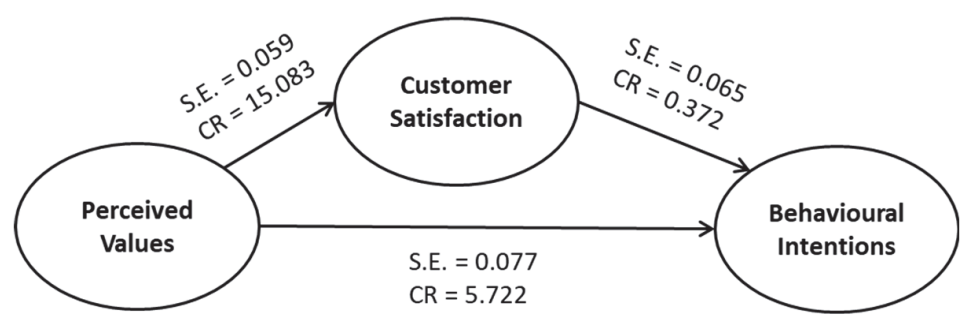

Fig. 3. Mediation of customer satisfaction on relationship between Perceived Value and Behavioral Intentions

The results obtained from Table 6 were used for Sobel test using calculation for the online Sobel Test found on http://quantpsy.org/sobel/sobel.htm , and the results obtained are shown below in Table 7.

\section{Table 7}

Sobel Test results for mediation of customer satisfaction on the relationship between Service Quality and Behavioral Intentions

\begin{tabular}{ccc}
\hline & \multicolumn{2}{c}{ Results } \\
\hline Test & Statistics (Z-test) & 0.70997705 \\
Sobel & 0.37188691 & 0.71058335 \\
Aroian & 0.37107274 & 0.70936693 \\
\hline Goodman & 0.37270646 & 0 \\
\hline
\end{tabular}

The reported $p$-values are drawn from the unit normal distribution under the assumption of a two-tailed $z$-test of the hypothesis that the mediated effect equals zero in the population. $+/-1.96$ are the critical values of the test ratio which contain the central $95 \%$ of the unit normal distribution. The value 0.37188692 from the Z-test, and the p-Value of 0.70997705 indicates that the mediating effect of customer satisfaction on the relationship between service quality and behavioral intentions for this study is not supported. This study results in Maldives context and conducted in the medical care industry agrees with previous theoretical findings of Cronin et al., (2000) theory test using an interrelationship model for the healthcare service industry in the United States.

\subsection{Hypotheses testing and Results}

This study on medical care among Maldivians seeking medical care within medical tourism services provided empirical evidence and supported the first three hypotheses $\mathrm{H} 1, \mathrm{H} 2$, and $\mathrm{H} 3$ derived from literature reviews for this study. Hypothesis 4 
which checks the mediation effect of customer satisfaction on the relationship between Perceived Value and Behavioral Intention is not supported. Table 8 shows the results for hypothesis testing. The findings of this study are consistent with the results obtained from a previous research (Cronin et al., 2000) on a model of interrelationships.

Table 8

Results for hypotheses testing

\begin{tabular}{clc}
\hline H(x) & Hypotheses & Findings \\
\hline H1 & Perceived Value has a positive impact on customer satisfaction & Supported, based on Estimate and \\
H2 & Perceived Value has a positive impact on behavioral intentions. & C.R. results in Table 6 above \\
H3 & Customer Satisfaction has a positive impact on behavioral intentions. & Supported \\
\hline H4 & Customer Satisfaction mediates the relationship between Perceived Value and behavioral intentions. & Not Supported by Z-test results in \\
& & Table 7
\end{tabular}

\section{Conclusion}

This research refers to a conceptual model that considered perceived value and customer satisfaction as antecedents to behavioral intention. It examined the behavior among Maldivians' who received medical care facilities of medical tourism services. The findings suggest that perceived value contributes positively and significantly to customer satisfaction as well as to behavioral intention. Customer satisfaction has a direct significant effect on behavioral intention. The mediation of customer satisfaction on the relationship between perceived value and behavioral intention is not supported although the P value is significant, as the results revealed that the intensity of the relationship is considered to be too weak, and does not confirm a sufficient relationship to support the hypothesis H4. From this study it can be inferred that the findings for medical care within medical tourism services in the Maldives shows a pattern close to that of empirical findings on the healthcare industry in the United States, conducted by Cronin et al. (2000) model of interrelationship. In the context of Maldivians seeking medical care within medical tourism related services, perceived value has both direct and indirect effects on behavioral intention. More significantly, this research being the first of its kind as it generalizes the findings in the context of Maldivians' behavioral intention to demonstrate the mediating role of customer satisfaction between the perceived value and behavioral intention for medical care within medical tourism services. This work enriches the literature on medical care and medical tourism, illustrating the importance of understanding the interrelationships between perceived value, customer satisfaction and customers' behavioral intentions when providing medical care services from various service providers to medical seeking customers in the South East Asia region.

\subsection{Study Implications}

The findings obtained from this study enhance and enriches the literature on medical care and medical tourism with an emphasis on the South Asia region, where there is inadequate research conducted highlighting the significance of perceived value, customer satisfaction and behavioral intention in pursuing medical care in Maldives context. Study also implies that medical industry managers and marketers should exercise the internal and external determinants which affects and are related to particular customer behavior which depicts moments of truth in their respective product or service experience journey to receive a particular product or service, indicating that a positive attitude should also be created by the marketeers to build customer satisfaction during the concept, package and process of their new medical care products and services. Providing best solutions with enhanced customer perceived value for the customers will help medical care service providers achieve a higher level of customer satisfaction and improve customers' behavioral intention to visit, revisit or achieve word-of-mouth advocacy to respective service providers. Medical industry related policy and procedures may also be redesigned and harmonized with medical value standards, and provide a future direction to improvise the Maldives national healthcare strategy in order to strengthen the perceived value generations and improve customer satisfaction levels, and futuristic programs applied in the medical care industry towards attaining health and medical accreditation global standards in the near future.

\subsection{Limitations and directions for future research}

Limitations in literature as selected search choices only in English Language. This study was carried at the level of an atoll, rather than at individual island levels. Approach to data collection since this research is a cross-sectional sample in a noncontrive setting, as it is possible to change over time, since the interpretation and beliefs of individuals about their experience vary with time. Thus, future research in the Maldives context, but conducted with a longitudinal study at island level instead of atoll level may possibly provide a different set of results.

\section{Acknowledgements}

Grateful to all the survey participants without whose response this study would not have been possible. A special mention of Survey administrators who successfully facilitated the survey across the 19 atolls. Sincere appreciation to academics and professionals in the health and medical care industry who provided insights from the relevant experience, knowledge and learning to improve the instrument selection for this study. 


\section{References}

Aburayya, A., Al-Marzouqi, A., Alawadhi, D., Abdouli, F., \& Taryam, M. (2020). Am empirical investigation of the effect of employees' customer orientation on customer loyalty through mediating role of customer satisfaction and service quality. Management Science Letters, 10(2020), 2147-2158.

Adikaram, C. A. N. K., \& Khatibi, A. (2016). The relationship between customer relationship management and customer satisfaction: A study on private higher education institutions in Sri Lanka. International Journal of arts and Commerce, $5(2), 69-95$.

Ahn, J. \& Thomas, T. K. (2020). The role of customers' perceived value of integrated resort brands in destination. Journal of Destination Marketing \& Management, 15 (2020) 100403. Https://doi.org/10.1016/j.jdmm.2019.100403.

Ahmed, S., Tariq, K. M., \& Arif, I. (2017). Service quality, patient satisfaction and loyalty in the Bangladesh healthcare. International Journal of Health Care Quality Assurance. 30(5), 477-488.

Ajzen, I. (2020). The theory of planned behavior: Frequently asked questions. Human Behavior \& Emerging Technology, (2020), 1-11. DOI: 10.1002/hbe2.195.

Ajzen, I. (1991). The Theory of Planned Behavior" Organizational Behavior and Human Decision Process, 50(2), $179-211$.

Al-Gharaibah, O. B. (2020). Customer retention in five-star hotels in Jordan: The mediating role of hotel perceived value. Management Science Letters, 10(2020), 3949-3956.

Albattat, A. R. \& Romli, S. R. M. (2017). Determining visitors' repetition by using Servqual dimensions in attraction park: a case from Kuala Lampur, Malaysia. International Journal of Applied Business and Economic Research, 15(15), $351-371$.

Altaf, M., Tabassum, N., \& Mokhtar, S. S. M. (2018). Brand equity and the role of emergency medical care service quality of private cardiac institutes: An empirical investigation. International Journal of Pharmaceutical and Healthcare Marketing, 12(1), 44-60.

Awn, A. M., \& Azam, S. M. F. (2020). The influence of attitude and subjective norm on intention to invest in Islamic bonds (sukuk): a study of Libyan investors. International Journal of Business Society, 4(4), 27-33.

Bandalos, D. L. (2018). Measurement Theory and Applications for the Social Sciences. New York: The Guilford Press.

Bezerra, G. C. L., \& Gomes, C. F. (2020). Antecedents and consequences of passenger satisfaction with the airport. Journal of Air Transport Management, 83(2020) 101766. Https://doi.org/10.1016/j.jairtraman.2020.101766.

Barari, M., Ross, M., \& Surachartkumtonkum, J. (2020). Negative and positive customer shopping experience in an online context. Journal of Retailing and Consumer Services, 53,101985.

Chahal, H. \& Kumari, N. (2012). Consumer perceived value: the development of a multiple item scale in hospitals in the Indian context. International Journal of Pharmaceutical and Healthcare Marketing, 6(1), 167-190.

Chatterjee, S., Shainesh, G., \& Sravanan, C. N. S. (2018). Does intention translate into action? Investigating the impact of loyalty intention on future usage. Journal of Indian Business Research, 10(2), 151-169.

Chen, C. F., \& Tsai, D. C. (2007). How Destination Image And Evaluative Factors Affect Behavioral Intentions. Journal of Tourism Management, 28(1), 1115- 1122.

Chenal, H., \& Bala, M. (2010). Significant components of service brand equity in healthcare sector. International Journal of Health Care, 25(4), 343-362.

Cronin, J. J., Brady, M. K., \& Hult, G. T. M. (2000). Assessing the effects of quality, value, and customer satisfaction on consumer behavioral intentions in service environments. Journal of Retailing, 76(2), 193-218.

Duhachek, A., Coughlan, A. T., \& Iacobucci, D. (2005). Results on the Standard Error of the Coefficient Alpha Index of Reliability. Marketing Science, 24(2), 294-301.

Eggert, A., \& Ulaga, W. (2002). Customer perceived value: A substitute for satisfaction in business markets? Journal of Business \& Industrial Marketing, 17(2/3), 107-118.

Fitriani, D. Y., Pasinringi, S. A., \& Amqam, H. (2019). The Effect of Perceived Value on Patient Satisfaction in Public University Hospital in Makassar. East African Scholars Journal of Medical Sciences, 2(7), 410-412.

Fornell, C., Johnson, M.D., Anderson, E.W., Cha, J.S. \& Bryant, B.E. (1996). The American customer satisfaction index: nature, purpose, and findings, Journal of Marketing, 60(4), 7-18.

Grönroos, C. (2017). On value and value creation in service: a management perspective. Journal of Creating Value, 3(1), 117.

Gronroos, C. (1990). Service Management and Marketing: Managing the Moments of Truth in Service Competition, Lexington Books: Lexington, MA.

Hair, J. F., Black, W. C., Anderson, R. E., \& Babib, B. J. (2019). Multivariate data analysis (8 ${ }^{\text {th }}$ ed.). London: Cengage Learning.

Haji, S. A., Surachman, Ratnawali, K., \& Rahayu, M. (2021). The effect of experience quality, perceived value, happiness and tourist satisfaction on behavioral intention. Management Science Letters, 11(2021), 1023-1032.

Haque, A., Chowdhury, N. A., \& Tarofder, A. K. (2020). Purchase Intention towards Alternative Medicine: A Study from Consumers' Perspective in Malaysia. Iranian Journal of Public Health, 49(1), 193-195. Doi:10.18502/ijph.v49i1.3071.

Hayat, D. T., \& Esenyel, I. (2020). Effect of perceived stakeholder conflict factors on guests' satisfaction and behavioral intention and mediation effect of guests' perceived value: Evidence from Hospitality sector of Northern Cyprus. Management Science Letters, 10(20), 3783-3792.

Health, Ministry of. (2017). National Mental Health Policy 2015-2025, Health, M.O. (ed): Maldives. Retrieved November 29, 2020, from http://health.gov.mv/Uploads/Downloads//Informations/Informations(67).pdf 
Health, Ministry of. (2019). Maldives Health Research Bulletin, Vol. VI, Health, M. O. (ed.): Maldives. Retrieved November 29, 2020, from http://health.gov.mv/Uploads/Downloads//Publications/Publication(61).pdf

Hekkert, K. D., Cihangir, S., Kleefstra, S. M., Van den Berg, B. \& Kool, T. (2009). Patient satisfaction revisited: A multilevel approach. Social Science Medicine, 69(1), 68-75.

Holbrook, M. B. (1994). The nature of customer value: An axiology of services in the consumption experience. In R. T. Rust \& R. L. Oliver (Eds.), Service quality: New direction on theory and practice: Sage Publication.

Hu, L. \& Bentler, P. M. (1999). Cutoff criteria for fit indexes in covariance structure analysis: Conventional criteria verses new alternatives. Structural Equation Modeling, $\underline{6}(1), 1-55$.

Karunaratna, A. C. S. \& Kumari, P. A. P. S. (2018). Determinants of customer loyalty: A literature review. Journal of Customer Behavior, 17(1/2), 49-73.

Kotler, P., Amstrong, G. (2004). Principles of Marketing. Upper Saddle River: NJ Prentice Hall.

Knoll, E. (2017). Archipelagic genes: Medical travel as a creative response to limitations and remoteness in the Maldives. Asia Pacific Viewpoint, 58(20), 48-161.

Konuk, F. A. (2019). The influence of perceived food quality, price fairness, perceived value and satisfaction on customers' revisit and word-of-mouth intentions towards organic food restaurants. Journal of Retailing and Consumer Services, 50(2019), 103-110.

Lin, L. \& Huang, S. (2018). Modeling Chinese Post-90s' Tourism Loyalty to the Ex-rival State Using the Perceived Value Approach. Tourism and Hospitality Management, 24(1), 23-40.

Mahmoud, M. A., Hinson, R. E., \& Anim, P. A. (2018). Service innovation and customer satisfaction: the role of customer value creation. European Journal of Innovation Management, 21(1), 402-422.

Martinaityte, I., Sacramento, C., \& Aryee, S. (2019). Delighting the customer: Creativity-oriented high-performance work systems, frontline employee creative performance, and customer satisfaction. Journal of Management, 45(2), 728-751. doi:10.1177/0149206316672532.

National Bureau of Statistics - Maldives. (2019). Maldives in figures - May 2019, National Bureau of Statistics Maldives. Retrieved November 21, 2020, from http://statisticsmaldives.gov.mv/maldives-in-figures-may-2019/

National Bureau of Statistics - Maldives. (2020). National Summary Data Page (NSDP) - Maldives. Retrieved November 27. 2020, from http://statisticsmaldives.gov.mv/nsdp/

Nunnally, J. C. (1978). Psychometric theory. 2nd Edition, McGraw-Hill, New York.

Oh, H. (1999). Service quality, customer satisfaction, and customer value: A holistic perspective. International Journal of Hospitality Management, (1999), 18(1), 67-82.

Oliver, R. L. (1980). A cognitive model of antecedents and consequences of satisfaction decisions. Journal of Marketing Research, 17(4), 460-469.

Oliver, R. L. (2014). Satisfaction: A Behavioral Perspective on the Consumer, Routledge: New York, NY.

Parasuraman, A., Zeithaml, V. A., \& Berry, L. L. (1985). A conceptual model of service quality and its implication for future research. Journal of Marketing, 49(4), 10-16.

Parasuraman, A., Zeithaml, V. A., \& Berry, L. L. (1988). "SERVQUAL: A Multiple Item Scale for Measuring Consumer Perceptions of Service Quality”. Journal of Retailing, 64(1), 12-40.

Patterson, P. G., \& Spreng, R. A. (1997). Modelling the relationship between perceived value, satisfaction and repurchase intentions in a business-to-business, services context: an empirical examination. International Journal of Service Industry Management, 8(5), 414-434.

Rahayu, Y. S., Setiawan, M., Jrawanto, D. W., \& Rahayu, M. (2020). Muslim customer perceived value on customer satisfaction and loyalty: Religiosity as a moderation. Management Science Letters, 10(5), 1011-1016.

Sharma, V. (2017). Patient satisfaction and brand loyalty in healthcare organizations in India. Journal of Asia Business Studies, 11(1), 73-87. https://doi.org/10.1108/JABS-09-2015-0157.

Singh, R. \& Soderlund, M. (2020). Extending the experience construct: an examination of online grocery shopping. European Journal of Marketing, Vol, ahead of print, No. ahead of print. https//doi:10.1108/EJM-06-2019-0536.

Sudari, S. A., Tarofder, A. K., Khatibi, A., \& Tham, J. (2019). Measuring the critical effect of marketing mix on customer loyalty through customer satisfaction in food and beverage products. Management Science Letters, 9(9), 1385-1396.

Waheed, N. \& Hassan, Z. (2016). Influence of Customer Perceived Value on Tourist Satisfaction and Revisit Intention: A study on Guesthouses in Maldives. International Journal of Accounting, Business and Management, 4(1), $101-123$.

Willis, L., Lee, E., Renolds, K. J., \& Klik, K. A. (2020). The Theory of Planned Behavior and the Social Identity Approach: A New Look at Group Processes and Social Norms in the Context of Student Binge Drinking. Europe's Journal of Psychology, 2020, 16(3), 357-383. https://doi.org/10.5964/ejop.v16i3.1900.

Zeithaml, V.A. (1988). Customer perceptions of price, quality and value: a means-end model and synthesis of evidence. Journal of Marketing, 52(3), 2-22.

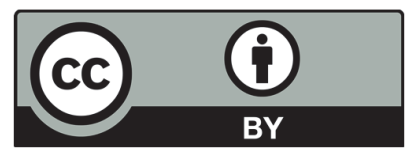

(C) 2021 by the authors; licensee Growing Science, Canada. This is an open access article distributed under the terms and conditions of the Creative Commons Attribution (CC-BY) license (http://creativecommons.org/licenses/by/4.0/). 